\title{
Tempo Comunidade como estratégia da interculturalidade epistemológica - a experiência do curso de Licenciatura Intercultural indígena da UFPE/CAA
}

\author{
ALMEIDA, Eliene Amorim de ${ }^{1}$ \\ ANDRADE, Flávio Lyra de ${ }^{2}$
}

\section{RESUMO}

Este artigo é fruto da nossa experiência como docentes do Tempo Comunidade (TC) do Programa de Formação de Professores Indígenas realizado pela Universidade Federal de Pernambuco - Campus do Agreste (UFPE/CAA) Curso de Licenciatura Intercultural Indígena. No texto apresentamos as inquietações e reflexões sobre como garantir que as comunidades e os indígenas fossem assumidos, nesse curso, como espaços e sujeitos epistêmicos e como os conhecimentos indígenas poderiam ser objetos de diálogo com os saberes acadêmicos atribuindo à interculturalidade crítica (WALSH, 2009; TUBINO, 2005, 2012) o sentido de interepistemologias (MIGNOLO, 2003, 2008, 2010). Para elaborar a proposta do TC, baseamo-nos nas concepções de educação popular e da pesquisa participante, na forma como elas se configuraram na América Latina (BRANDÃO; STRECK, 2006; STRECK; ESTEBAN, 2013), e embasados no Pensamento Decolonial (WASLH, 2009; MIGNOLO, 2003, GROUSFOGUEL, 2010).

Licenciatura Intercultural Indígena. Educação Popular. Pesquisa Participante. Tempo Comunidade.Interepistemologia.

\section{ABSTRACT}

This article is the result of our experience as Community Time (CT) teachers of the Indigenous Teacher Training Program conducted by the Federal University of Pernambuco-Agreste Campus (UFPE/CAA) - Indigenous Intercultural Degree Course. In the text we present the concerns and reflections on how to ensure that communities and indigenous people were assumed in this course as spaces and epistemic subjects and how indigenous knowledge could be objects of dialogue with academic knowledge attributing critical interculturality (WALSH, 2009;

\footnotetext{
${ }^{1}$ Doutora em Educação pela Universidade Federal de Pernambuco. Mestre em educação pela Universidade Federal de Pernambuco. Professora da Faculdade Frassineti do Recife - FAFIRE. E-mail: elieneamorimdealmeida62@gmail.com. Lattes: http://lattes.cnpq.br/0217330129788168. ORCID: https://orcid.org/0000-0003-4194-3534.

${ }^{2}$ Doutor em Sociologia pela Universidade Federal da Paraíba, Membro do Grupo de Pesquisa Religiões, Identidades e Diálogos da Pós-graduação em Ciência da Religião - UNICAP e Educador Popular. E-mail: flyraa62@gmail.com. Lattes: http://lattes.cnpq.br/9286329222257353. ORCID: https://orcid.org/0000-0002-7010-6797.
}

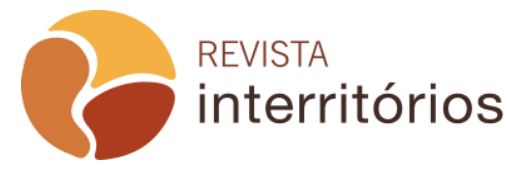


TUBINO, 2005, 2012) in the meaning of interepistemologies (MIGNOLO, 2003, $2008,2010)$. To elaborate the proposal of CT we werebased on the conceptions of popular education and the participatory research as they were configured in Latin America (BRANDÃO; STRECK, 2006; STRECK; ESTEBAN, 2013), and based on the Decolonial Thought (WASLH, 2009; MIGNOLO, 2003, GROUSFOGUEL, 2010).

Indigenous Intercultural Degree.Popular Education.Participating Research. Community Time. Interepistemology.

Tempo in comunittá come strategia di interculturalità epistemologica l'esperienza del corso di laurea interculturale indigena UFPE/ CAA

\section{RIASSUNTO}

Questo articolo è il risultato della nostra esperienza come insegnanti di Community Time (TC) del Programma di formazione per insegnanti indigeni condotto dall'Università Federale del Campus di Pernambuco-Agreste (UFPE/ CAA BRASILE) - Corso di laurea interculturale indigeno. Nel testo presentiamo le preoccupazioni e le riflessioni su come garantire che le comunità e gli indigeni siano stati assunti in questo corso, come spazi e soggetti epistemici e come la conoscenza indigena possa essere oggetto di dialogo con conoscenze accademiche che attribuiscono interculturalità critica (WALSH, 2009; TUBINO, 2005,2012 ) il significato delle interepistemologie (MIGNOLO, 2003, 2008, 2010). Per elaborare la proposta ci siamo basati sulle concezioni dell'educazione popolare e della ricerca partecipativa così come sono state configurate in America Latina (BRANDÃO; STRECK, 2006; STRECK; ESTEBAN, 2013) e basate sul Decolonial Thinking (WASLH, 2009; MIGNOLO, 2003, GROUSFOGUEL, 2010).

Laurea Indigena Interculturale. Educazione Popolare. Ricerca Partecipante.

Tempo dela Comunità. Interepistemologia.

\section{Tempo Comunidade como estrategia de interculturalidad epistemológica: la experiencia del curso de Grado Intercultural Indígena UFPE / CAA}

\section{RESUMEN}

Este artículo es el resultado de nuestra experiencia como maestros de Community Time (TC) del Programa de Formación de Maestros Indígenas realizado por la Universidad Federal de Pernambuco - Campus Agreste (UFPE / CAA) - Curso de Grado Intercultural Indígena. En el texto presentamos las preocupaciones y reflexiones sobre cómo garantizar que las comunidades y los pueblos indígenas se asuman en este curso como espacios y temas epistémicos y cómo el conocimiento indígena podría ser objeto de diálogo con el conocimiento académico que se atribuye a la interculturalidad crítica (WALSH, 2009; TUBINO, 2005, 2012) el significado de las interepistemologías (MIGNOLO, 
2003, 2008, 2010). Para elaborar la propuesta de la CT, nos basamos en las concepciones de la educación popular y la investigación participativa, tal como se configuraron en América Latina (BRANDÃO; STRECK, 2006; STRECK; ESTEBAN, 2013), y en base al Pensamiento descolonial (WASLH, 2009; MIGNOLO, 2003, GROUSFOGUEL, 2010).

Grado Intercultural Indígena. Educación popular. Investigación participante. Comunidad del tiempo. Interepistemología.

Um pouco de história da criação Programa de Formação de Professores Indígenas realizado pela Universidade Federal de Pernambuco - Campus do Agreste (UFPE/CAA) - Curso de Licenciatura Intercultural Indígena

Este artigo é fruto da nossa experiência como docentes do Tempo Comunidade, no Programa de Formação de Professores Indígenas realizado pela Universidade Federal de Pernambuco - Campus do Agreste (UFPE/CAA) - Curso de Licenciatura Intercultural Indígena.

A licenciatura intercultural, específica para formar docentes indígenas, faz parte de um conjunto de reivindicações desses povos, tendo em vista fortalecer as suas escolas e, consequentemente, seus projetos societários. O curso da UFPE/CAA teve duas versões: a primeira foi realizada no período 2009-2012 e a segunda entre 2014-2018; as duas etapas ocorreram no Campus Agreste, na cidade de Caruaru, subordinado ao Núcleo de Formação Docente.

Esse curso é fruto das lutas dos movimentos indígenas no Brasil. Em Pernambuco, com o surgimento da Comissão de Professores(as) Indígenas de Pernambuco (COPIPE) em 1999, o movimento de professoras e professores indígenas se fortalece e começa a intervir de forma articulada nas ações educacionais desenvolvidas pela secretária de educação e também a reivindicar vários direitos, entre eles: a participar no Núcleo de Educação Escolar Indígena (NEEI) da secretaria estadual da educação; realizar reuniões entre os diversos povos indígenas em Pernambuco; realizar encontrões ${ }^{3}$, conferências, seminários para discutir e propor a política educacional para seus povos.

Nesses eventos foram produzidos vários documentos que tratam das suas reivindicações acerca de suas demandas educacionais, quais sejam: currículo intercultural; criação da categoria professora e professor indígena; a regularização da carreira; o concurso público específico; o reconhecimento do

3 Assim chamados pelos indígenas os espaços onde os educadores, educadoras e lideranças indígenas em Pernambuco trocam experiências, discutem seus projetos, planejam e avaliam suas práticas pedagógicas e elaboram suas pautas e estratégias de lutas para garantir seus direitos. 
modelo de gestão de acordo com a organização social de cada povo; criação de normas específicas dentro da Secretaria Estadual de Educação (COPIPE, 2000, $\mathrm{s} / \mathrm{p}$ ). Esses temas continuam na pauta sem serem atendidos pelos gestores públicos mesmo com uma legislação educacional específica sobre o tema.

Somadas a essas reivindicações, novas demandas são criadas pelo movimento indígena, principalmente o direito ao ensino em nível superior específico e diferenciado para formar indígenas como docentes voltados a ensinar nas escolas nos seus territórios.

Assim, no início dos anos 2000, com a criação da categoria de escola indígena, o movimento começou a reivindicar a existência de curso de licenciatura específico para formar indígenas que atuavam em suas escolas sem a escolarização adequada para a segunda fase do ensino fundamental e médio da educação básica.

Dessa forma, inicia-se um processo de mobilização e articulação com vários segmentos governamentais e não governamentais que culminaria, em 2009, na criação do Programa de Educação Intercultural da Universidade Federal de Pernambuco (UFPE/CAA).

Esse processo de mobilização e articulação para garantir o curso de licenciatura intercultural para indígenas ganhou força em outubro de 2006 quando ocorreu o I Fórum sobre a Educação Superior Indígena, organizado pela Escola Superior de Educação Física da Universidade Estadual de Pernambuco (ESEF/UPE) no contexto da VI Semana Universitária da UPE.

No Fórum, ficou estabelecida a urgência da criação de um programa de formação intercultural para formar indígenas que atuassem nos diversos níveis de ensino e modalidades da educação básica. Foi deliberado ainda que o curso de licenciatura para formar docentes indígenas funcionaria na UFPE/CAA, na cidade de Caruaru, devido à existência de um Núcleo de Formação de Professores e por oferecer as condições institucionais e administrativas necessárias para a implementação do curso (PPC/UFPE/CAA, 2006, p. 1).

Os cursos de licenciaturas interculturais específicos para indígenas atuarem como docentes no Brasil surgem no contexto de reivindicações e conquistas dos povos indígenas pela garantia do Ensino Superior, respeitando suas filosofias, suas organizações e suas cosmovisões. As Licenciaturas Interculturais têm sido um denominador comum no atendimento às demandas desses grupos étnicos e que, aos poucos, vêm sendo incorporadas aos programas das Instituições Públicas de Ensino Superior (IES).

Para organizar e desenvolver esses cursos, uma das diretrizes anunciadas pelos documentos do Ministério da Educação (MEC) e Conselho Nacional de Educação (CNE) é que a elaboração das propostas pedagógicas desses cursos aconteça de forma coletiva. Essa lógica das propostas pedagógicas das licenciaturas interculturais serem elaboradas em parcerias com

\begin{tabular}{l|l} 
REVISTA & Interritórios
\end{tabular} $\begin{aligned} & \text { Interritórios| Revista de Educação } \\
& \text { Universidade Federal de Pernambuco, } \\
& \text { Caruaru, BRASIL | V.5 N.9 [2019] }\end{aligned}$


apoio de vários sujeitos sociais, especialmente do movimento indígena, tem sido uma experiência de várias IES do Brasil, orientação das diretrizes da Política Nacional de Educação Escolar e exigência posta pelo Edital do Programa de Licenciaturas Indígenas (PROLIND), como mostra o trecho do Edital de Convocação no 03 de 2008, quando trata dos critérios para aprovação das propostas das IES e afirma que "as propostas deverão ter como base a manifestação explícita de interesse por parte dos beneficiários, bem como, estar adequadas à realidade social e cultural específica de cada povo" (BRASIL, 2008, p. 4).

Em Pernambuco, a exemplo do que ocorre no Brasil, o curso de licenciatura foi fruto de um processo de mobilização e articulação de vários processos e iniciativas desenvolvidas por sujeitos sociais diversos: indígenas, indigenistas, organizações de apoio a causa indígena, professores e professoras ligadas(os) às universidades públicas (UPE, UFPE, UFRPE), e com apoio do PROLIND.

A versão do primeiro projeto para criação da licenciatura especificamente para formar docentes foi amplamente discutida com representantes das organizações indígenas e, sobretudo, com a Comissão de Professores Indígenas de Pernambuco (COPIPE), representantes da sociedade civil através das organizações não governamentais, tais como Centro de Cultura Luiz Freire (CCLF), e, professores(as) das IES públicas de Pernambuco e representantes de autoridades acadêmicas da Universidade Federal de Pernambuco (PPC/UFPE/CAA, 2006, p. 2).

Além desse processo de articulação e mobilização dos sujeitos locais, a criação desse curso deu-se também, a nosso ver, por fatores nacionais e locais. Em âmbito nacional a conjuntura favoreceu, tendo em vista, as políticas desenvolvidas pelo governo federal. Estamos nos referindo à criação do Programa de Expansão das Universidades Públicas do governo federal, explicitamente nos governos do Presidente Lula (2002-2006; 2005-2009). Nesse contexto, a UFPE expandiu seu campo de atuação, anteriormente sediada apenas em Recife, para as cidades de Vitória de Santo Antão e Caruaru, o que possibilitou a criação de novos cursos de graduação, oportunizando atender melhor à população do interior do Estado, entre elas os indígenas, como mostra o texto do PPC/UFPE/CAA que segue:

Com a implantação do processo de interiorização da Universidade Federal de Pernambuco e a criação do Campus de Caruaru, esse projeto está sendo adequado para que seja implementado em sua totalidade no Centro Universitário do Agreste através do Núcleo de Formação de Docentes do Campus de Caruaru da UFPE, de acordo com o Seminário Interinstitucional realizado em Caruaru no dia 14 de setembro de 2006, promovido pela Pró-Reitoria Acadêmica. Uma das resoluções foi dar encaminhamentos no I Fórum Educação 
Superior Indígena no dia 3 de outubro quando instituída uma comissão interinstitucional para finalizar a elaboração do Projeto. (2006, p. 4).

Além disso, em 2008, em uma parceria entre o Ministério da Educação (MEC), por intermédio da Secretaria de Educação Continuada, Alfabetização e Diversidade (SECAD), da Secretaria de Ensino Superior (SESU) e do Fundo Nacional de Desenvolvimento da Educação (FNDE), foi publicado o segundo Edital de Convocação do Programa de Licenciaturas Indígenas(PROLIND), quando a UFPE/CAA, com o Projeto elaborado, se candidatou ao Edital de Convocação no 3 de 24 de junho desse mesmo ano, e teve seu projeto aprovado.

Foi, então, nesse contexto de reivindicação, mobilização e articulação do movimento indígena, de ampliação dos campi universitários por parte do Governo Federal, e a consequente interiorização da UFPE, o apoio financeiro do PROLIND somado às articulações e a vontade política-pedagógica dos diversos sujeitos, especialmente docentes da UPE e UFPE, que estão ligados à problemática da educação escolar indígena em Pernambuco, que o "Programa de Formação de Professores Indígenas de Pernambuco - curso de licenciatura intercultural Indígena" ganhou sua primeira versão no período de 2009 a 2012 e, depois uma nova turma, entre 2014 e 2018 , formando um total aproximado de 300 (trezentos) docentes indígenas.

Nos documentos oficiais do MEC, na Proposta Pedagógica do Curso da UFPE/CAA, e nas reivindicações da COPIPE, anuncia-se que o currículo da formação docente deve ser intercultural, como pode ser constatado na seguinte afirmação:

O processo de formação dos professores indígenas deve ser baseado na interculturalidade de saberes como princípio epistemológico para isso é necessário que se estabeleça uma relação de diálogo entre as culturas indígenas e a ciência moderna, como pressuposto da ação pedagógica e do processo formativo. (PPC/UFPE/CAA, 2006, p. 7, grifos nossos).

Da mesma forma, o MEC, no Portal da Secretaria de Educação Continuada, Alfabetização, Diversidade e Inclusão (SECADI), tratando do PROLIND, informa que o principal objetivo do programa é "apoiar financeiramente cursos de licenciatura especificamente destinados à formação de professores de escolas indígenas, as chamadas licenciaturas indígenas ou licenciaturas interculturais" (BRASIL, 2005, s/p).

A COPIPE também compreende que o curso de licenciatura para formação docente de indígenas em Pernambuco deve ser intercultural, como mostra trecho da carta a SECADI, 
estamos apoiando as iniciativas das universidades públicas de Pernambuco que demonstram interesse em realizar cursos de licenciaturas interculturais para que resolva parte dos nossos problemas enquanto professores indígenas. (COPIPE, s/d).

É sobre a exigência da interculturalidade na formação da docência indígena, no currículo prescrito e na sua vivência do curso, especialmente na análise do Tempo Comunidade, como possibilidade de se tornar espaço/tempo privilegiado para produzir um conhecimento outro (MIGNOLO, 2003) que vamos tratar a seguir.

\section{O currículo prescrito do Curso da UFPE/CAA: o anúncio do Tempo Comunidade, como estratégia da interculturalidade epistemológica}

O curso de licenciatura, na primeira turma (2006) e segunda (2014) da UFPE/CAA, teve como objetivo formar e habilitar docentes indígenas em Licenciatura Plena em Educação Intercultural, nas áreas de concentração: Linguagem e Artes; Ciências da Terra e da Natureza e Ciências Humanas e Sociais, de forma que possam atuar nas Escolas indígenas de Ensino Fundamental e de Ensino Médio, como mostra o texto do PPC/UFPE/CAA:

O educador licenciado pelo Curso deverá ser capaz de atuar nos diferentes níveis e modalidades da Educação Básica. As áreas desta atuação, que deverão encampar os programas curriculares diferenciados, definidos pelas escolas, serão: Línguas, Artes, Literaturas, Matemática, Ciências da Natureza, Ciências Sociais e Humanidades. (2006, p. 9).

Os componentes curriculares do curso estão organizados em três grupos de saberes: comuns, específicos e práticos. Segundo o PPC do curso (2006), o "grupo de saberes comuns" é desenvolvido nos dois primeiros anos do curso para todas(os) as(os) estudantes, independente da área de conhecimento escolhida pela (o) estudante no vestibular e

contemplam os conteúdos científicos e culturais dispostos nas seguintes áreas: Saberes da área cultural; Saberes da área pedagógica; saberes da área de linguagem e artes; Saberes da área de ciências da terra e da natureza; Saberes da área de ciências humanas e sociais. (2006, p. 17).

Ainda segundo o PPC do curso de 2006, o grupo de saberes específicos tem como conteúdo "um grupo de saberes de natureza científica e cultural específicos (2006, p. 18)" de acordo com as áreas de conhecimentos escolhidas das(os) estudantes. 
O terceiro, e último grupo, seria o de saberes práticos, que contempla atividades de natureza científico-cultural, Trabalho de Conclusão de Curso (TCC) e Estágios Curriculares Supervisionados.

Para garantir que o seu funcionamento atendesse à realidade dos povos indígenas, a proposta pedagógica da primeira versão do curso (2009-2012) anuncia que a Licenciatura deve funcionar na modalidade presencial e semipresencial, já que o público é de indígenas que estão no exercício da profissão docente. $\mathrm{Na}$ segunda versão do curso, o termo é trocado para "alternância pedagógica".

$\mathrm{Na}$ proposta pedagógica de 2006, para garantir a "sistemática de concretização do curso", especialmente o módulo semipresencial, o documento anuncia várias estratégias: organizar grupos de trabalhos, monitoria, laboratórios interculturais, realização de projetos de pesquisa e a produção de material didático. Esse conjunto de estratégias, segundo o PPC, visava estabelecer um diálogo entre dois tempos do curso: presencial e semipresencial, articulando as atividades realizadas nos dois territórios: Comunidades Indígenas e Campus da UFPE.

As estratégias propostas (grupos de trabalho e monitoria) visavam articular as diversas atividades pedagógicas com o intuito de que as pesquisas pudessem ser realizadas de forma a subsidiar os componentes curriculares da modalidade presencial.

A intenção de promover a pesquisa dos conhecimentos indígenas como estratégia de funcionamento do curso nos pareceu bastante coerente já que o PPC do curso anunciava que a formação de docentes indígenas iria ocorrer na perspectiva da interculturalidade, como princípio epistemológico, como pode ser observado no trecho do documento da PPC/UFPE/CAA, que segue:

O professor indígena deve passar por um processo de formação que atenda às especificidades postas pela natureza das escolas indígenas, cujo princípio epistemológico básico será o da interculturalidade, que está na base desse projeto de licenciaturas. (2006, p.6).

De fato, a pesquisa no processo de formação de indígenas como docentes, como pesquisadoras(es) de seus próprios conhecimentos é reivindicação do movimento indígena, exigência dos vários documentos legais e defendida na literatura pertinente como condição essencial para que a escola e a formação de docentes indígenas sejam desenvolvidas em uma perspectiva interepistemológica e intercultural.

Partimos do pressuposto de que é no processo de formação da(o) indígena, como docente, especialmente no módulo presencial/Tempo Universidade, que os(as) estudantes poderiam receber subsídios teóricos e 
práticos sobre pesquisa, de forma que o semipresencial/Tempo Comunidade fosse o espaço/tempo da sua realização. Esses saberes/conhecimentos registrados voltariam ao Tempo Universidade, onde seriam sistematizados, organizados e postos em discussão e diálogo com os saberes acadêmicos. Dessa forma, os(as) estudantes teriam subsídios para pensar o currículo intercultural das escolas de educação básica nas quais são docentes em suas aldeias.

Entretanto, Almeida (2017), na sua pesquisa de doutorado, nos informa que a pesquisa no curso de Licenciatura Indígena da UFPE/CAA ocorreu sobre alguns aspectos da vida dos povos indígenas "e ligadas a alguns componentes curriculares: história, religião, arqueologia, educação e só na primeira parte do curso, ou seja, nos dois primeiros anos, quando estava sendo vivenciado o grupo de saberes comuns" (p.183-184). Contudo, nos dois anos seguintes, no desenvolvimento dos grupos de saberes específicos, a atividade de pesquisa não foi desenvolvida. Melhor dizendo, no momento em que as(os) estudantes foram se dedicar aos componentes curriculares das áreas de saberes, aquelas que elas(es) vão ensinar nas escolas indígenas, a pesquisa parou de acontecer e os conteúdos da fase presencial se limitaram aos conhecimentos ditos "universais", transmitidos na academia para todos(as).

O que se constatou é que um dos elementos mais significativos que impede que o currículo da formação de docentes indígenas seja desenvolvido em uma perspectiva interepistemológica é o critério da racionalidade moderna eurocêntrica, que não permite que possam emergir saberes outros, mantendo ocultos os modos de pensar outros, as formas outras de ler o mundo, mantendoos "no descrédito, na inexistência" (ARROYO, 2011, p. 141).

A pesquisa como estratégia de diálogo e sistematização dos conhecimentos/saberes indígenas seria a possibilidade que a IES teria de promover a Ecologia dos Saberes (SANTOS, 2010).

$\mathrm{Na}$ perspectiva da interculturalidade como interepistemologia, a investigação sobre os conhecimentos indígenas nos parece ser de fundamental importância para orientar os componentes curriculares do curso, de forma que os saberes indígenas tenham lugar privilegiado no desenvolvimento das áreas de conhecimento, cabendo ao cursista, junto com docente do Tempo Universidade, com apoio de um instrumental metodológico adequado, fazer o levantamento, sistematizar e colocar em diálogo com os outros conhecimentos que circulam no módulo presencial ${ }^{4}$.

4 O fato do curso não ter um corpo docente exclusivo, e mais ainda, a descontinuidade de docentes como professores visitantes, que ministraram as disciplinas para a Licenciatura, dificultou a geração de uma dinâmica onde fosse experimentada a proposição do diálogo de saberes da comunidade indígena e da comunidade acadêmicas.

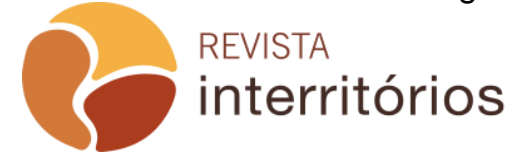


Todavia, na vivência curricular, analisa Almeida (2017), abandonou-se a compreensão dos indígenas e seus territórios como sujeitos e espaços epistêmicos, considerando-os apenas como consumidores dos conhecimentos já produzidos no contexto da epistemologia do ponto zero. Para Castro Gomez, trata-se de:

ter o poder de nomear pela primeira vez o mundo; de traçar fronteiras para estabelecer quais conhecimentos são legítimos e quais são ilegítimos, definindo quais comportamentos são normais e quais são patológicos. Por isso, o ponto zero é o do começo epistemológico absoluto, mas também o do controle econômico e social sobre o mundo. Localizar-se no ponto zero equivale a ter o poder de instituir, de representar, de construir uma visão sobre o mundo social e natural reconhecida como legítima e autorizada pelo Estado. Trata-se de uma representação na qual os "varões ilustrados" se definem a si mesmos como observadores neutros e imparciais da realidade. (CASTRO-GOMEZ, 2005, p. 25).

Confirma-se, assim, a compreensão de Santos (2010), quando afirma que o conhecimento científico eurocêntrico reivindica para si a verdade e, ao mesmo tempo, inviabiliza formas de conhecimentos outros que não se encaixam na epistemologia dominante, notadamente os "conhecimentos populares, leigos, plebeus, camponeses, ou indígenas" (p. 33).

No período de desenvolvimento dos componentes curriculares das áreas de saberes específicos, as atividades desenvolvidas no tempo semipresencial (Tempo Comunidade) foram "as tarefas de casa", ou seja, os saberes já prontos, nos quais couberam apenas às(aos) estudantes solucionar os problemas à luz dos conhecimentos produzidos pela modernidade eurocêntrica, sem compreender a lógica de sua construção ou aplicar a sua própria lógica de conhecimento. Para Almeida (2017, p.192):

tratava-se mesmo, de um grande desafio já que as IES, como Instituição própria do Projeto Moderno, têm tradição de praticar o racismo epistêmico (GROSFOUGUEL, 2010), em relação aos conhecimentos que têm matrizes epistemológicas diferentes da modernidade, sendo considerados sem validade científica, que excluiu, desprestigiou os conhecimentos/saberes outros.

Assim, mesmo que no currículo prescrito tenha-se anunciado, com relação aos saberes do curso, o exercício da interepistemologia, utilizando-se da pesquisa como estratégia para coleta e sistematização dos conhecimentos dos povos indígenas e promovendo o diálogo sem hierarquizações entre esses conhecimentos com aqueles veiculados nas IES, não foi vivenciado, principalmente naqueles componentes curriculares ligados aos saberes 
clássicos das ciências modernas, matemática, física, química (ALMEIDA, 2017, p. 190).

Na versão de 2014, o Projeto Político Pedagógico (PPP) do curso ${ }^{5}$ de Licenciatura Intercultural, tratando da alternância pedagógica, afirma que o curso "é presencial adotando-se a Alternância Pedagógica como metodologia, em consonância com o prescrito no Edital da SECADI/MEC № 2, de 27 de agosto de 2013", que segundo o documento da PPP/UFPE/CAA, diz que:

a organização curricular por etapas cumpridas em Regime de Alternância entre Tempo/Universidade e Tempo/Comunidade, entendendo-se por Tempo/Universidade os períodos intensivos de formação presencial no campus universitário e, por Tempo/Comunidade, os períodos intensivos de formação presencial nas comunidades indígenas, com a realização de práticas pedagógicas orientadas.

Ainda analisando a alternância pedagógica como estratégia metodológica necessária e adequada à realidade dos povos indígenas o documento PPP/UFPE/CAA afirma que:

\begin{abstract}
Assim, no tempo universidade, vivenciado nas dependências do Centro Acadêmico do Agreste da UFPE, são trabalhados os saberes próprios dos componentes curriculares e, ao mesmo tempo, os subsídios teórico-metodológicos para a prática docente e para o desenvolvimento de pesquisa. No tempo comunidade, busca-se vivenciar e integrar tais conhecimentos com a realidade indígena de modo a retroalimentar o tempo universidade vindouro, constituindose assim os ciclos de saberes. De fato, o tempo comunidade é um espaço que amplia as reflexões do tempo universidade quando os professores em formação, a partir da problematização da realidade onde atuam, desenvolvem atividades de pesquisa para serem compartilhadas no retorno ao tempo universidade, ciclicamente (2014, p. 23, grifos nossos).
\end{abstract}

Como pode ser observado na proposta de 2016, não se faz referência à possibilidade do Tempo Comunidade (TC) ser território epistêmico, espaço de pesquisa, produção e sistematização dos conhecimentos indígenas, pois, no Tempo Comunidade apenas se "amplia as reflexões do Tempo Universidade, tendo em vista que busca-se vivenciar e integrar os conhecimentos do Tempo Universidade com a realidade indígena”, abandonando-se assim, na prática, a ideia de um curso intercultural.

5Na versão de 2016, a proposta pedagógica do curso é intitulada Projeto Político Pedagógico.

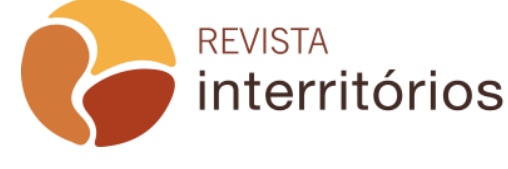


Pode-se perceber o abandono da ideia de interculturalidade e mais precisamente da interespitemologia que havia sido explicitada na proposta pedagógica de 2006, quando afirmou:

A formação do professor deve subsidiá-lo para que ele possa desenvolver atividades de pesquisador, sistematizador dos saberes de suas culturas e organizar conteúdos que irão nortear o currículo escolar; o processo de formação dos professores indígenas deve ser baseado na interculturalidade de saberes como princípio epistemológico para isso é necessário que se estabeleça uma relação de diálogo entre as culturas indígenas e a ciência moderna, como pressuposto da ação pedagógica e do processo formativo (2006, p. 7, grifos nossos).

Para Walsh (2008) há concepções diferentes de interculturalidade, o tema é polivocal e polissêmico (ALMEIDA, 2017). Os Movimentos Sociais Ancestrais (indígenas e afro) quando tratam de interculturalidade exigem mudanças nas atuais estruturas do Estado-nação. Nesse contexto, a interculturalidade não existe enquanto fato dado, não é contexto construído, estabelecido a priori, é projeto em construção, porque ela é mais do que reconhecimento da diversidade.

A Interculturalidade Crítica ou Interepistemologia é um projeto social, político, econômico, cultural e epistêmico que exige uma estrutura outra de Estado e de modos de vida. A Interculturalidade exige uma discussão sobre Projeto Moderno, das heranças coloniais, da epistemologia do ponto zero. Necessita de práticas sociais, políticas, educacionais, culturais outras. Para Walsh (2008), a Interculturalidade da forma requerida pelos movimentos indígenas,

tienen que ver con la cosmología de la vida en general, incluyendo los conocimientos y saberes, la memoria ancestral, y la relación con la madre naturaleza y la espiritualidad, entre otras. Por sí, parte del problema de las relaciones y condiciones históricas y actuales, de la dominación, exclusión, desigualdad e inequidad como también de la conflictividad que estas relaciones y condiciones engendran, es decir la "colonialidad» con sus cuatro ejes o potestades ya señalados. (2008, p. 141).

Portanto, não basta ter um curso intitulado "licenciatura intercultural", e que no currículo prescrito seja anunciada a interculturalidade, é necessário que na execução sejam desenvolvidas estratégias para garantir o anúncio.

Há também uma outra concepção de interculturalidade: a Funcional (TUBINO, 2005; SARTORELLO, 2009; WALSH, 2009a). Nessa perspectiva, incorpora-se as demandas dos povos ancestrais como uma estratégia para a manutenção da hegemonia do Estado-nação. Suas bases estão fincadas na oficialização da Interculturalidade. É o que parece que ocorreu no curso de 
licenciatura intercultural indígena. A UFPE atendeu à demanda dos povos indígenas e criou um curso específico com recursos do PROLIND, recebeu estudantes de todos os povos indígenas do estado de Pernambuco, nomeou o curso de intercultural, mas na sua execução, especialmente no que diz respeito aos conhecimentos que circularam, foram privilegiados os saberes ditos universais, sem diálogo com os saberes indígenas, até porque não se desenvolveram estratégias para sistematizar esses saberes.

O que nos parece que permeia essa concepção é a ideia de que há um conhecimento único, verdadeiro e universal. Como já dissemos, a proposta pedagógica do curso foi elaborada envolvendo vários sujeitos sociais, o que possibilitou que o desenho, o conteúdo, as ideias, as concepções e as análises postas no documento, ou seja, o currículo prescrito, fosse construído de forma conjunta, por isso mesmo, as concepções do documento, assim como a sua vivência, estão sujeitas às contradições, aos limites e às possibilidades postas nesse contexto de diálogos múltiplos e da Diferença Colonial (MIGNOLO, 2003). Portanto, a concepção que permeia o currículo intercultural está sujeita à polissemia e polivocalidade inerente ao conceito de interculturalidade.

A nosso ver, isso fica evidenciado nas duas versões de propostas pedagógicas do curso de licenciatura intercultural indígena desenvolvidas pela UFPE/CAA, aquilo que Grosfoguel (2007) chama de racismo epistêmico, que

é um dos racismos mais invisibilizados no "sistema-mundo capitalista/patriarcal/ moderno/ colonial". O racismo em nível social, político e econômico é muito mais reconhecido e visível que o racismo epistemológico. Este último opera privilegiando as políticas identitárias (identitypolitics) dos brancos ocidentais, ou seja, a tradição de pensamento e pensadores dos homens ocidentais (que quase nunca inclui as mulheres) é considerada como a única legítima para a produção de conhecimentos e como a única com capacidade de acesso à "universidade" e à "verdade". O racismo epistêmico considera os conhecimentos não-ocidentais como inferiores aos conhecimentos ocidentais. (2007, p.32).

O fato do Tempo Comunidade (TC) ter se tornado um espaço de realização de tarefas de casa, perdendo sua concepção original de espaço/tempo de produção, sistematização dos conhecimentos indígenas, promovendo a interculturalidade epistemológica, gerou inquietações nos(as) estudantes, na COPIPE e em alguns professores(as) da UFPE.

A partir de uma avaliação do curso e da necessidade de ter professores(as) acompanhando as atividades do Tempo Comunidade, a coordenação da licenciatura intercultural indígena, na metade da realização segunda turma, publica o Edital 01/2015 para selecionar professores(as) para: 
atuarem na Licenciatura Intercultural Indígena - CAA - UFPE. Para que atuem nos módulos presenciais de 60h semestrais ou 120 horas anuais como limita o Decreto N. 6.114, de 15 de maio de 2007, publicado no DOU de 16.05.2007, que rege o pagamento de profissionais neste programa na UFPE. O curso possui tempo universidade e tempo comunidade que constituem a alternância Pedagógica. Os professores poderão atuar ministrando no tempo universidade na UFPE/CAA, nas aldeias indígenas, no acompanhamento do tempo comunidade, no estágio supervisionado e TCCs. ( $p$. 1 , grifos nossos).

Para a Alternância Pedagógica, foram selecionadas 10 (dez) pessoas, sendo 4 (quatro) não indígenas e 6 (seis) indígenas ${ }^{6}$. É esse grupo que questionaria o modelo de "tarefas de casa" que o Tempo Comunidade havia se tornado e desencadearia uma reflexão acerca da concepção de interculturalidade na Licenciatura Indígena.

\section{Tempo Comunidade a proposta da interculturalidade como interepistemologia}

A partir da compreensão de Interculturalidade como exigência epistemológica na formação de indígenas como docentes, o grupo de professoras(es) do Tempo Comunidade elaborou uma proposta de trabalho (TC) considerando as comunidades indígenas como tempo/espaços de produção de conhecimentos.

Duas questões nos mobilizaram para refletir sobre o TC:

(1) Como superar a lógica de que o Tempo Comunidade se restringe às "tarefas de casa", ou seja, que ele não seja meramente um prolongamento da disciplina em voga nas aldeias, mas sim, uma "ponte" que relacione os saberes acadêmicos e os saberes dos povos indígenas? (2) Como o Tempo Comunidade pode ser a engrenagem que impulsiona a prática de interculturalidade no desenvolvimento do curso da Licenciatura Intercultural a medida que é o espaço concreto onde os estudantes podem pesquisar e sistematizar os saberes indígenas? (2016, p.3).

O primeiro passo do grupo de professores(as) do Tempo Comunidade foi se debruçar sobre a temática da Alternância Pedagógica (STRECK; ESTEBAN,

6 Indígenas: Elisa Urbano Ramos; Expedito Lino; Maria Luciete Lopes; José Agnaldo Gomes de Souza; Francisca Bezerra da Silva; Thiago Torres de Lima. Não indígenas: Alexandre Oliveira Gomes; Eliene Amorim de Almeida; Flávio Lyra de Andrade; Lara Erendira Almeida de Andrade. 
2013; BRANDÃO, 2002; MOURA,2003) e em aportes teóricos e metodológicos advindos de experiências de trabalho com Educação Escolar Indígena, as experiências de pesquisa da COPIPE, a Educação Popular e a perspectiva Decolonial em Educação, assim como de abordagens antropológicas, históricas e sociológicas voltadas a uma intervenção político-pedagógica de viés sentirpensante (BORDA, 2009), alinhados às reflexões acerca das Epistemologias do Sul.

O que nos mobilizou a realizar os estudos foi a indagação sobre as possíveis contribuições que essas concepções teórico-metodológicas poderiam nos ajudar a encontrar uma forma do Tempo Comunidade se tornar espaço/tempo de pesquisa e registro dos saberes indígenas.

Esse exercício recolocou, em novo contexto, perguntas que se interpuseram, já no momento de criação do curso como adotar uma perspectiva intercultural crítica.

Quando avaliamos como vinha ocorrendo o Tempo Comunidade, debatendo sobre as práticas Alternância Pedagógica, na Educação do Campo ${ }^{7}$, fizemos uma retrospectiva do que tinha sido a experiência do Laboratório Intercultural na forma como foi desenvolvido no texto do PPC de 2006.

Nessa proposição estava previsto o uso de caderno de campo pelos(as), estudantes da Licenciatura, como forma de registro de suas experiências no Tempo Comunidade, ocupando um lugar estratégico, para proporcionar o diálogo necessário entre os conhecimentos das comunidades indígenas e da comunidade acadêmica.

Posto esse desafio, e com uma equipe de professores e professoras do Tempo Comunidade de formação interdisciplinar, composta por indígenas e não indígenas, dessa forma, pode-se lidar com as questões levantadas, beneficiando-se de experiências diferentes e diversos aportes teóricos e metodológicos.

No processo de construção coletiva da proposta, usufruímos de práticas profissionais e militantes nos campos: da educação popular, do indigenismo e da etnografia, do debate sobre interculturalidade e educação escolar indígena, do debate sobre epistemologias do sul e decolonialidade, das práticas de registro e sistematização de experiências - a exemplo da elaboração de livros realizada por indígenas sob coordenação do Centro de Cultura Luiz Freire (CCLF) e COPIPE.

7 No Campus do Agreste, no mesmo período do desenvolvimento das turmas de Licenciatura Intercultural também foram realizadas atividades com grupos da educação do campo, e algumas das professoras que atuavam com as turmas de estudantes indígenas também atuavam com educação do campo e trouxe a experiência da Alternância Pedagógica para a formação de docentes indígenas.

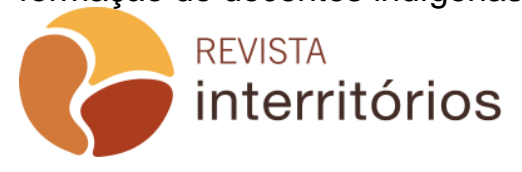


Inspirados por essas reflexões iniciais, concluímos que o Tempo Comunidade (TC) seria um espaço-tempo de pesquisa participante. Não sem antes fazer uma leitura histórica da tradição da educação popular, situando-a no lugar potencialmente ocupado pela pesquisa participante, no que ela consegue articular, construir sínteses, a partir de diferentes contribuições políticas pedagógicas ao longo de décadas de história (BRANDÃO; STRECK, 2006; WANDERLEY, 2006; SOUZA, 2006).

O debate sobre pesquisa participante surgiu no interior da educação popular, entendida como espaço de reflexão das práticas educativas e políticas realizadas por educadores(as) e intelectuais. Estes atuavam em escolas, universidades, organizações de formação para movimentos sociais, entidades que atuavam com desenvolvimento comunitário, educação de adultos e cultura popular. Podemos localizar este debate nos anos 1960, destacando a contribuição fundante de Paulo Freire, com as experiências do Movimento de Cultura Popular (MCP), Serviço de Extensão Universitária (SEU), Alfabetização de Adultos em Angicos-RN (FAVERO, 1983; FREIRE, 2008; ROSAS, 2002).

Nas décadas de 1970 e 1980, a educação popular incide também nas praticas de organizações de direitos humanos e educação política, no combate às ditaduras militares, na luta pela democracia e organização dos trabalhadores e camponeses na América Latina e no Brasil.

Nesse contexto, dos anos 1960 a 1980, a educação popular, a pesquisa participante e a pesquisa-ação emergem como uma corrente de pensamento de educadores(as) comprometidos(as) com um processo de transformação da sociedade. Desenvolveu-se uma compreensão sobre a produção do conhecimento, que implicava num diálogo com os setores populares e seu envolvimento na construção do conhecimento e participação na política para enfrentar as desigualdades sociais.

A tradição da Educação Popular, por um lado, construiu-se em um diálogo com várias experiências: trabalhos de assistência técnica-social e desenvolvimento de comunidade - principalmente rural -, trabalhos de organização social e educação de base de organismos da Igreja Católica em suas experiências de Ação Católica especializada ${ }^{8}$ e sua metodologia do verjulgar-agir, e experiências de formação política em centros de cultura e educação popular. Tais experiências tiveram forte ênfase no debate sobre o funcionamento e transformação da sociedade, da participação política e dos direitos de trabalhadores(as), camponeses(as), mulheres, negros e quilombolas, povos indígenas, crianças e adolescentes, deficientes físicos (PAIVA, 1986; BRANDÃO, 1982a; BOFF, 1984, ANDRADE, 2012).

8 Juventude Operária Católica (JOC), Juventude Agrária Católica (JAC), Animação dos Cristãos no Meio Rural (ACR), Juventude Universitária Católica (JUC) e Movimento de Educação de Base (MEB).

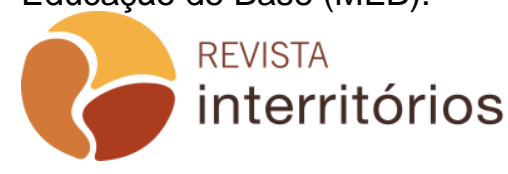


A ação de educação popular manteve viva a luta histórica por uma educação pública e de qualidade, de valorização da cultura popular, enfrentando o grande desafio de combater analfabetismo, o que a leva a desenvolver uma gama de ações de alfabetização de jovens e adultos, de defesa do direito da educação pública gratuita para todos(as) até integrar hoje propostas que visam garantir, além da universalidade do acesso, uma educação que reconheça outros sujeitos, outras pedagogias e a exigência da interculturalidade (GADOTTI; TORRES,1999, ARROYO, 2012; FREIRE; NOGUEIRA, 1991; SOUZA, 2001; PONTUAL; IRELAND, 2006).

A pesquisa participante questiona sobre quem elabora 0 conhecimento. Fals Borda (1982), o pioneiro no desenvolvimento dessa abordagem de pesquisa e educação, relaciona ciência dominante e ciência emergente, construindo para isso o conceito de ciência popular - parâmetro político-ideológico-epistemológico. $O$ autor indica como princípios gerais para esse tipo de pesquisa: autenticidade e compromisso, antidogmatismo, restituição sistemática, feedback para os intelectuais orgânicos, ritmo e equilíbrio de ação-reflexão, ciência modesta e técnicas dialogais.

Brandão (1987) enfatiza nas suas reflexões sobre cultura o relacionamento entre a teoria e o modo como o pesquisador atua. Centrado nessa preocupação, agrupa noções que entende como imprescindíveis para o delineamento da pesquisa participante. Para ele:

a) só se conhece em profundidade alguma coisa da vida da sociedade ou da cultura, quando, através de um envolvimento de alguns casos, um comprometimento pessoal entre o pesquisador e aquilo, ou aquele, que ele investiga; b) não é propriamente um método objetivo de trabalho cientifico que determina a priori a qualidade da relação entre os polos da pesquisa, mas, ao contrário, com frequência, é a intenção premeditada, ou a evidencia realizada de uma relação pessoal e/ou política estabelecida, ou a estabelecer, que sugere a escolha dos modos concretos de realização do trabalho de pensar a pesquisa; c) em boa medida, a logica, a técnica e a estratégia de uma pesquisa de campo dependem tanto de pressupostos teóricos quanto da maneira como o pesquisador se coloca na pesquisa e através dela e a partir daí constitui simbolicamente o outro que investiga. (p. 8).

Por vezes, a pesquisa participante e pesquisa ação se confundem. No entanto, Thiollent (1986-1987) distingue a pesquisa-participante e a pesquisa-ação insistindo que não são sinônimas. A pesquisa-ação faz parte de um projeto de ação social ou de resolução de problemas coletivos. Ela supõe que haja apoio do movimento, da organização social, cultural, educacional, sindical ou política na qual está concentrada. Ela não é unidisciplinar nos processos de investigação, pois podem pesquisar \begin{tabular}{l|l} 
REVISTA & Interritórios| Revista de Educação
\end{tabular} 
especialistas de várias disciplinas.

O fundamental é que a pesquisa-ação tem um desenho que torna possível, segundo sua linguagem, efetuar várias sínteses na resolução de problemas com a participação de analistas e usuários, com isso identificando problemas relevantes na realidade investigada, estruturando uma explicação dos problemas, definindo um programa de ação para o enfrentamento dos problemas selecionados e priorizados, acompanhando os resultados da ação em todas as fases. Tal processo que pode favorecer uma generalização do conhecimento, acumulando o aprendido em cada uma das fases.

As reflexões de Brandão (2007) sobre pesquisa-participante coincidem com as contribuições de Boaventura de Sousa Santos sobre uma ciência pós-moderna. Nesse esforço ele indica alguns procedimentos que continuam sendo atuais na tradição da educação popular e da pesquisa-participante expressos na dinâmica do

i) retorno ao diálogo com o senso comum nas culturas populares e das comunidades dos excluídos; ii) na ruptura com os velhos modos de pensar, de educar e de investigar a realidade, fundados na lógica utilitária do mercado; iii) no deslocamento do lugar social da busca de sentidos e de projetos de construção da história do poder totalitário e do mundo dos negócios para a sociedade civil, e, nela, para a esfera das comunidades e dos movimentos populares; iv) na construção de modelos de educação e de pesquisa fundados no diálogo e na dissolução da hierarquia de competentes desiguais em nome da interação igualitária entre cocriadores diferentes. (p. 47, grifos nossos).

Sendo assim, o grupo do Tempo Comunidade reafirmou a necessidade do agente da pesquisa sobre os saberes indígenas ser o intelectual e/ou educador de dentro da realidade cultural que será observada, ou seja, o próprio estudante indígena. Ele é membro da comunidade que será o espaço do exercício do "estranhamento" necessário à prática da observação participante e ao registro etnográfico (AMGROSINO, 2009).

Essa concepção foi sistematizada no documento intitulado "Orientação para a realização do Tempo Comunidade no âmbito da Licenciatura Intercultural Indígena", no qual é apresentada a proposta do Tempo Comunidade numa perspectiva teórica e operacional, que busca traduzir essa nova perspectiva de alternância pedagógica, com base na ideia de interculturalidade crítica.

Essa abordagem reforça a busca de um diálogo entre saberes acadêmicos e saberes tradicionais e a não reprodução do padrão universalista de produção do conhecimento e ensino presente na tradição pedagógica da modernidade ocidental eurocêntrica. Como diz o texto do documento: 
O Tempo Comunidade é o espaço, na estrutura de funcionamento do curso da Licenciatura Intercultural, que possibilita uma prática sistemática de construção de "pontes" entre os saberes indígenas e os saberes da universidade ou, mais amplamente ainda, de informar a universidade sobre os conhecimentos dos povos indígenas, garantindo assim a materialização da recorrente referência abstrata à prática de interculturalidade. Para isso, faz-se necessário que os estudantes sejam preparados para uma "intervenção pedagógica" de forma que possam sistematizar os conhecimentos de seus povos e trazerem para o Tempo Universidade. (LICENCIATURA INTERCULTURAL INDÍGENA, 2016, s/p).

Ao optarmos por adotar a pesquisa-participante como formato, para dar corpo à estrutura do Tempo Comunidade, elaboramos um Projeto de Intervenção Pedagógica.

Definiu-se que a intervenção pedagógica se articulará com a realização semestral dos Laboratórios Interculturais, produzindo a partir do recolhimento e sistematização das notas de campo tomadas com a observação. Esse material deveria servir de subsídio para as disciplinas dos módulos do Tempo Universidade, do semestre seguinte à realização do Laboratório.

Na sequência, apresentamos um fluxograma do percurso, que orientou a construção do Projeto de Intervenção Pedagógica. O fluxograma representa a dinâmica adotada, a partir das fases previstas para construção e desenvolvimento da ação pedagógica em planejamento. Destaca-se nele a adoção de uma perspectiva pedagógica e metodológica, que é o referencial teórico adotado, como pesquisa participante, adequado e recriado para responder à concepção intercultural adotada.

Figura 1: Fluxograma da construção do Projeto de Intervenção Pedagógica

\section{Tempo Comunidade Intercultural}

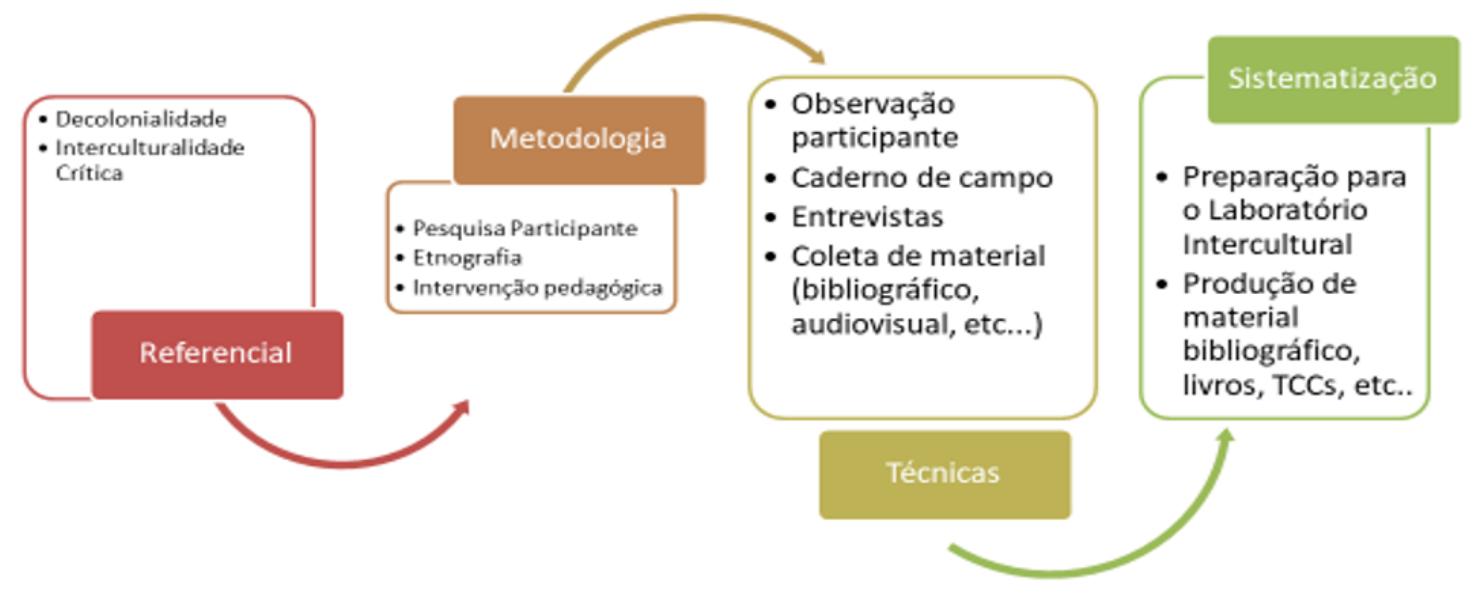

Fonte: Elaborado pelo grupo de Professores(as) do Tempo Comunidade. 
Para dar concretude ao Projeto de Intervenção Pedagógica elaboramos um roteiro de questões para levantamento e registro de elementos do modo de vida, saberes e práticas dos povos e comunidades indígenas e dos(as) estudantes do curso. Para tanto, tomamos por referências os eixos do Projeto Político Pedagógico das Escolas Indígenas dos Povos, que são:

\section{Quadro 1: Eixos estruturadores da Educação Escolar Indígena}

\begin{tabular}{|c|c|}
\hline Terra/Território & $\begin{array}{l}\text { O fortalecimento do território como espaço sagrado de resistência, coletivamente } \\
\text { habitada pelos indígenas, de interação com a Mãe Natureza, depositando o significado } \\
\text { e sentido na construção do projeto de futuro e o lugar de moradia dos antepassados, } \\
\text { dos mitos e conhecimentos tradicionais. }\end{array}$ \\
\hline Organização & $\begin{array}{l}\text { A organização social e política de cada povo indígena como elemento importante de } \\
\text { sustentação da educação escolar, em que o papel estratégico da escola indígena é } \\
\text { contribuir para o fortalecimento da identidade étnica e cultural do povo. É através dela } \\
\text { que são realizados os processos de luta e conquistas, garantindo assim o direito a } \\
\text { escola, a saúde, as políticas agrícolas, entre outros. }\end{array}$ \\
\hline História & $\begin{array}{l}\text { A história dos povos indígenas, respeitando e valorizando os saberes dos mais velhos, } \\
\text { tendo como referência a vida dos nossos antepassados, aqueles (as) que vivenciaram } \\
\text { uma história de sofrimento e perseguição, mas também de resistência em prol de uma } \\
\text { luta coletiva. }\end{array}$ \\
\hline Identidade & $\begin{array}{l}\text { A reafirmação e o fortalecimento identitário compreende múltiplas dimensões que } \\
\text { envolvem o pertencimento étnico, a partir do cotidiano, através do vínculo com a } \\
\text { terra/território e com as tradições culturais, na relação com os não indígenas e na } \\
\text { reivindicação pela garantia de direitos. }\end{array}$ \\
\hline Bilinguismo & $\begin{array}{l}\text { Promover o ensino da Língua Indígena do povo, assegurando o ensino e } \\
\text { aprendizagem, a valorização, a manutenção e visando garantir a preservação da língua } \\
\text { materna e cultura dos povos indígenas. }\end{array}$ \\
\hline $\begin{array}{l}\text { Interculturalidad } \\
\mathbf{e}\end{array}$ & $\begin{array}{l}\text { A interculturalidade é um projeto de vida coletivo construído a partir de pensamento } \\
\text { outro }^{9} \text {, de conhecimento outro, é o reconhecimento do ser e do fazer numa perspectiva } \\
\text { da equidade, da justiça, numa relação também de conflito sim, mas que trata de dar } \\
\text { visibilidade aos que ficaram invisíveis no processo de colonização e na prática da } \\
\text { colonialidade }{ }^{10} \text {. E buscar transformar as estruturas hegemônicas de poder das } \\
\text { instituições colonizadoras. É construir estratégias entre os que lutam pela } \\
\text { transformação na busca de condições humanas. Esse pensar é entender que cada } \\
\text { povo ou grupo social tem uma cultura própria, diferente uma das outras. Todavia, as } \\
\text { sociedades em geral tem uma tendência de achar que seu modo de vida é o mais } \\
\text { correto - postura etnocêntrica. Isso tem causado ao longo dos anos uma intolerância, } \\
\text { chegando ao total desrespeito ou mesmo a negação do outro. Para que nossos/as } \\
\text { estudantes conheçam e respeitem as diferentes formas de viver em sociedade, o } \\
\text { pensamento intercultural busca transformar as estruturas, as instituições, as relações } \\
\text { sociais e requer condições para diferentes formas de vida, do viver, do estar, conhecer, } \\
\text { aprender, sentir e do ser. }\end{array}$ \\
\hline
\end{tabular}

Fonte: Documento do Currículo intercultural da educação escolar indígena de Pernambuco, (2018, p.22).

9 O pensamento outro também denominado de pensamento de fronteira "significa tornar visíveis outras lógicas e formas de pensar, diferente da lógica eurocêntrica dominante (...) se preocupa com o pensamento dominante, mantendo como referência, mas sujeitando ao constante questionamento e introduzindo nele outras, história e modo de pensar". (OLIVEIRA; CANDAU, 2010, p. 25).

10 Segundo Quijano (2007, p. 93) "A colonialidade é um dos elementos constitutivos e específicos do padrão mundial do poder capitalista. Se funda na imposição de uma classificação racial/étnica da população mundial como pedra angular deste padrão de poder."

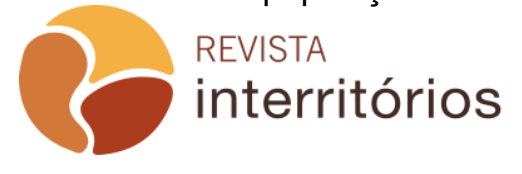


O debate sobre concepções e a construção criativa de sínteses e proposições que guardassem coerência teórico metodológica foi sendo formulado, como exercício de construção coletiva do documento, que definiu o novo Tempo Comunidade e as responsabilidades dos(as) professores(as). O mesmo método ocorre na elaboração do instrumento de observação e registro para pesquisa de campo dos(as) estudantes, estruturado na forma de um roteiro com questões para investigação, como mostramos no quadro a seguir:

Quadro 2: Roteiro de observação para registro etnográfico

\begin{tabular}{|c|c|c|c|}
\hline \multirow[b]{2}{*}{ Eixos } & \multicolumn{3}{|c|}{ Áreas de habilitação } \\
\hline & I) Ciências da Terra e da Natureza & II) Ciências Sociais e Humanas & III) Linguagens e Artes \\
\hline $\begin{array}{l}\frac{0}{0} \\
\frac{\pi}{0} \\
\stackrel{0}{0} \\
\frac{0}{0} \\
\frac{0}{0} \\
\stackrel{-}{-}\end{array}$ & $\begin{array}{l}\text { - Que elementos da identidade estão } \\
\text { presentes na relação com a terra e a } \\
\text { natureza? } \\
\text { - Quais são os elementos encontrados no } \\
\text { território mais importantes para a } \\
\text { identidade étnica (ervas, alimentos, frutos, } \\
\text { plantas do mato e da roça, animais, } \\
\text { matérias primas de artesanato, etc.) e } \\
\text { como a comum } \\
\text { idade os processa (o que ela faz com } \\
\text { eles? Por ex.: usado no ritual, para fazer } \\
\text { remédio, para fazer artesanato, para servir } \\
\text { de alimentação, etc.) } \\
\text { - Qual a relação entre terra/natureza e a } \\
\text { identidade étnica de cada povo? }\end{array}$ & $\begin{array}{l}\text { - O que caracteriza a identidade étnica do } \\
\text { seu povo? } \\
\text { - Quais são os elementos (elementos } \\
\text { materiais, rituais, valores, etc...) que a } \\
\text { caracterizam? } \\
\text { - O que diferencia seu povo dos outros } \\
\text { povos e dos demais camponeses que são } \\
\text { vizinhos ao território? } \\
\text { - Quais são as tradições religiosas do seu } \\
\text { povo? } \\
\text { - Qual a importância delas para o } \\
\text { fortalecimento e manutenção da } \\
\text { identidade ao longo da história? } \\
\text { - No seu povo como são construídas as } \\
\text { outras identidades, que não aquelas } \\
\text { propriamente étnicas (como as } \\
\text { desenvolvidas nas relações de gênero, } \\
\text { raça, geração e classe)? } \\
\text { - Quais elementos da memória coletiva } \\
\text { são centrais na construção da identidade } \\
\text { do seu povo? } \\
\text { - Quais são os valores e princípios } \\
\text { (cosmovisão) que estão presentes na } \\
\text { construção das relações com o território, } \\
\text { natureza, animais, plantas...? }\end{array}$ & $\begin{array}{l}\text { - Quais as palavras ou } \\
\text { expressões características } \\
\text { da língua de seu povo } \\
\text { utilizadas hoje? } \\
\text { - Onde e em que contexto } \\
\text { ou situações estas } \\
\text { palavras/expressões são } \\
\text { utilizadas? } \\
\text { - Quais os significados } \\
\text { dessas palavras ou } \\
\text { expressões? } \\
\text { - Quais as formas de } \\
\text { linguagem/expressões/prá } \\
\text { ticas que representam } \\
\text { elementos de identidade } \\
\text { de cada povo } \\
\text { (festividades, } \\
\text { artes/artesanato, } \\
\text { celebrações, objetos } \\
\text { artísticos ou utilitários, } \\
\text { construções de } \\
\text { casas/habitações próprias } \\
\text { do povo, cânticos, } \\
\text { músicas, instrumentos, } \\
\text { ornamentos e pinturas } \\
\text { corporais, etc.)? }\end{array}$ \\
\hline 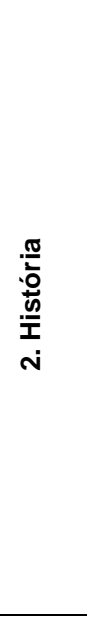 & $\begin{array}{l}\text { - Como se deram as transformações } \\
\text { na ocupação do território por parte } \\
\text { dos indígenas e dos invasores } \\
\text { (agricultura, pecuária, caça, } \\
\text { atividades de pesca e coleta etc.)? } \\
\text { - O que permaneceu e o que mudou } \\
\text { nas práticas de manejo do território } \\
\text { (formas de plantar, caçar, de usar os } \\
\text { recursos das matas/caatingas)? } \\
\text { - Quais a as práticas que o povo } \\
\text { encontrou (no passado e no } \\
\text { presente) para medir e contar que } \\
\text { representam de forma organizada as } \\
\text { atividades produtivas (volume, } \\
\text { medidas agrárias, formas de contar o } \\
\text { tempo, do calendário, etc.)? }\end{array}$ & $\begin{array}{l}\text { - Qual a história de origem do povo? } \\
\text { Como o território foi sendo ocupado } \\
\text { ao longo da história? } \\
\text { - Refletir sobre o contexto que levou } \\
\text { ao desaparecimento da língua } \\
\text { materna } \\
\text { - Qual a história de origem das } \\
\text { aldeias? } \\
\text { - Quais são as histórias sobre os } \\
\text { modos de viver do tempo dos } \\
\text { antigos? } \\
\text { - Quais foram as transformações que } \\
\text { aconteceram? }\end{array}$ & $\begin{array}{l}\text { - Qual a história e o } \\
\text { significado formas de } \\
\text { linguagem/expressões/ } \\
\text { práticas que } \\
\text { representam } \\
\text { elementos de } \\
\text { identidade de cada } \\
\text { povo? } \\
\text { a) Festividades, rituais, } \\
\text { celebrações, cânticos, } \\
\text { músicas; } \\
\text { b) Artes/artesanato, } \\
\text { objetos artísticos ou } \\
\text { utilitários da vida } \\
\text { cotidiana, instrumentos } \\
\text { musicais, ornamentos } \\
\text { o ninturas cornorais. }\end{array}$ \\
\hline
\end{tabular}




\begin{tabular}{|c|c|c|c|}
\hline \multirow[b]{2}{*}{ Eixos } & \multicolumn{3}{|c|}{ Áreas de habilitação } \\
\hline & $\begin{array}{l}\text { I) Ciências da Terra e da } \\
\text { Natureza }\end{array}$ & $\begin{array}{c}\text { II) Ciências Sociais e } \\
\text { Humanas }\end{array}$ & $\begin{array}{l}\text { III) Linguagens e } \\
\text { Artes }\end{array}$ \\
\hline 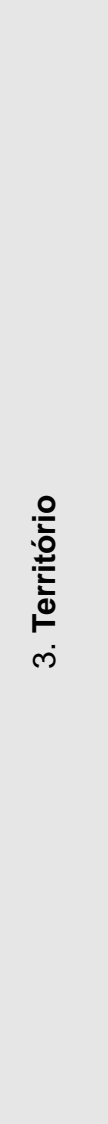 & $\begin{array}{l}\text { - Como se dá atualmente a } \\
\text { relação com a terra e a } \\
\text { natureza? } \\
\text { a) Quais são as práticas } \\
\text { produtivas existentes no } \\
\text { território? } \\
\text { b) Como os recursos das matas } \\
\text { são utilizados? } \\
\text { c) Como são feitos os plantios? } \\
\text { d) Uso de agrotóxico, adubos } \\
\text { naturais, tinturas, chás e } \\
\text { raizadas; } \\
\text { - Descreva o meio ambiente de } \\
\text { seu território, considerando } \\
\text { fauna, flora, relevo, clima e } \\
\text { hidrografia, solo (serras, fontes, } \\
\text { grutas, grotas, matas etc.) } \\
\text { - Quais as práticas tradicionais } \\
\text { de observação da natureza que } \\
\text { orientam a vida cotidiana } \\
\text { (plantio, caça, pesca etc.) }\end{array}$ & $\begin{array}{l}\text { - Quais são os espaços } \\
\text { importantes para seu povo? } \\
\text { - Quais deles se destacam } \\
\text { particularmente como relevante } \\
\text { símbolo da luta pela terra? } \\
\text { - E para religião? Como é a } \\
\text { relação do seu povo com ele? } \\
\text { - Como seu povo ocupa o } \\
\text { território? Quais as concepções } \\
\text { de agricultura? - Quais são as } \\
\text { formas de ocupar o território? } \\
\text { - Qual a relação com a mãe } \\
\text { natureza? } \\
\text { - Quais os valores em relação a } \\
\text { esse território? } \\
\text { - Quais as diferenças que seu } \\
\text { povo tem relativas à concepção } \\
\text { de agricultura, forma de ocupar o } \\
\text { território e valores que são } \\
\text { referentes a ele; pensando seu } \\
\text { povo em comparação aos } \\
\text { demais camponeses vizinhos, e } \\
\text { em relação aos fazendeiros? }\end{array}$ & $\begin{array}{l}\text { - Quais são os locais } \\
\text { do território onde } \\
\text { são encontrados, } \\
\text { processados } \\
\text { (fabricados) e } \\
\text { utilizadas as } \\
\text { matérias-primas? } \\
\text { - Quais são as } \\
\text { dificuldades de } \\
\text { acesso ao material } \\
\text { necessário para a } \\
\text { reprodução das } \\
\text { formas de } \\
\text { linguagem/expressõ } \\
\text { es/práticas que } \\
\text { representam } \\
\text { elementos de } \\
\text { identidade de cada } \\
\text { povo? } \\
\text { - Qual o local do } \\
\text { território onde são } \\
\text { realizadas } \\
\text { linguagem/expressõ } \\
\text { es/práticas que } \\
\text { representam } \\
\text { elementos de } \\
\text { identidade de cada } \\
\text { povo? }\end{array}$ \\
\hline 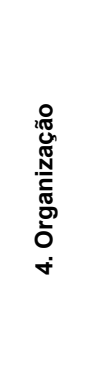 & $\begin{array}{l}\text { - Qual a relação da terra e da natureza } \\
\text { com a organização social do povo? } \\
\text { - Que saberes foram produzidos a partir da } \\
\text { relação entre terra/natureza e organização } \\
\text { social do povo? } \\
\text { - Como está distribuída a população nos } \\
\text { diversos ecossistemas da terra? } \\
\text { (Descrever as aldeias e o espaço onde } \\
\text { estão) }\end{array}$ & $\begin{array}{l}\text { - Como está organizado seu povo hoje? } \\
\text {-Como era a organização no tempo dos } \\
\text { mais velhos? } \\
\text { - Qual a diferença? } \\
\text { - Como a religião influencia na } \\
\text { organização social do seu povo? } \\
\text { - Quais foram as estratégias de } \\
\text { organização que seu povo utilizou ao } \\
\text { longo da história na luta pelo território } \\
\text { tradicional? E pelos demais direitos? }\end{array}$ & $\begin{array}{l}\text { - Quais os procedimentos, } \\
\text { processos, práticas, } \\
\text { saberes necessários para } \\
\text { a produção das formas de } \\
\text { linguagem, expressões, } \\
\text { práticas que representam } \\
\text { elementos de identidade } \\
\text { de cada povo? }\end{array}$ \\
\hline 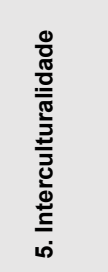 & $\begin{array}{l}\text { - Qual o lugar que os povos indígenas do } \mathrm{Na} \\
\text { utilizados na escola do povo em que seu ter } \\
\text { - Como o povo vem desenvolvendo ações } \\
\text { povo (pensando não só o ensino da temática } \\
\text { - Quais são as estratégias de articulação co } \\
\text { desigualdades sociais sofridas historicamen } \\
\text { - Como seu povo pensa as relações estabel } \\
\text { povos tradicionais, os camponeses vizinhos }\end{array}$ & $\begin{array}{l}\text { rdeste ocupam na versão da história nos livr } \\
\text { itório está inserido? E nos livros utilizados pe } \\
\text { educativas de viabilizar a garantia da Lei } 11.6 \\
\text { indígena, mas também afro-brasileira)? } \\
\text { m outros povos tradicionais, que seu povo te } \\
\text { e no nosso país? } \\
\text { ecidas com outros povos indígenas, e tambén }\end{array}$ & $\begin{array}{l}\text { las didáticos que estão sendo } \\
\text { las escolas indígenas? } \\
\text { m utilizado na luta contra as } \\
\text { n com quilombolas, outros }\end{array}$ \\
\hline
\end{tabular}

Fonte: LICENCIATURA INTERCULTURAL INDÍGENA/Professores do Tempo Comunidade. Registros do processo de elaboração da proposta do tempo comunidade intercultura indígena da UFPE/CAA (2015-2016). Caruaru: Coletânea de relatórios, documentos, textos (não publicado), UFPE-CAA, 2016. 
Com a definição desse modelo de funcionamento do Tempo Comunidade (TC), no documento "Orientações para a realização do Tempo Comunidade no âmbito da Licenciatura Intercultural Indígena" ficou o seguinte entendimento:

O Tempo Comunidade é o espaço, na estrutura de funcionamento do curso da Licenciatura Intercultural, que possibilita uma prática sistemática de construção de "pontes" entre os saberes indígenas e os saberes da universidade ou, mais amplamente ainda, de informar a universidade sobre os conhecimentos dos povos indígenas, garantindo assim a materialização da recorrente referência abstrata à prática de interculturalidade. Para isso, faz-se necessário que os estudantes sejam preparados para uma "intervenção pedagógica" de forma que possam sistematizar os conhecimentos de seus povos e trazerem para o Tempo Universidade. (2016, s/p).

Quando falamos em metodologia, num processo de intervenção em educação, distinguimos três elementos: a) as escolhas que fazemos do ponto de vista da estratégia da ação a ser desenvolvida, que tem a ver com a opção epistemológica que orienta nossa leitura da realidade social, o que implica em adotar determinados referenciais teóricos; b) a adoção de procedimentos e métodos de investigação, apoiados por técnicas de coleta e registro de informações; c) processamento, sistematização dos dados e elaboração de narrativa com análise dos dados. No entanto, na prática, esses elementos que orientam as pesquisas e suas metodologias interpenetram-se, ocorrem em momentos simultâneos e são intercambiáveis.

$\mathrm{Na}$ elaboração da proposta de intervenção pedagógica, seguimos algumas fases na forma como colocamos no quadro a seguir:

\section{Quadro 3: Plano de operacionalização da proposta de intervenção pedagógica}

\begin{tabular}{|c|c|c|c|c|}
\hline $\begin{array}{l}\text { Calendário } \\
\text { de trabalho } \\
\text { do TC }\end{array}$ & $\begin{array}{l}\text { Etapas da } \\
\text { Intervenção } \\
\text { Pedagógica } \\
\text { Participativa }\end{array}$ & $\begin{array}{c}\text { Referenciais } \\
\text { teórico- } \\
\text { metodológicos }\end{array}$ & $\begin{array}{l}\text { Debates e } \\
\text { Estudos }\end{array}$ & $\begin{array}{l}\text { Plano de Ação e } \\
\text { Execução/Produtos }\end{array}$ \\
\hline $1^{a}$ Fase & $\begin{array}{l}\text { - Avaliação do } \\
\text { TC } \\
\text { - Definição da } \\
\text { estratégia de } \\
\text { trabalho }\end{array}$ & $\begin{array}{l}\text { Tempo } \\
\text { Comunidade } \\
\text { Intercultural }\end{array}$ & $\begin{array}{l}\text { Debate do } \\
\text { grupo de } \\
\text { professores } \\
\text { Tempo } \\
\text { Comunidade }\end{array}$ & $\begin{array}{l}\text { Documento definindo } \\
\text { o que é Tempo } \\
\text { Comunidade e as } \\
\text { responsabilidades dos } \\
\text { professores(as) }\end{array}$ \\
\hline \multirow[t]{2}{*}{$2^{\mathrm{a}}$ Fase } & $\begin{array}{l}\text { Opção } \\
\text { epistemológic } \\
\text { a }\end{array}$ & $\begin{array}{l}\text { Pós(de)colonialidad } \\
\text { e }\end{array}$ & $\begin{array}{l}\text { Debate grupo } \\
\text { de } \\
\text { professores } \\
\text { Tempo } \\
\text { Comunidade } \\
\end{array}$ & $\begin{array}{l}\text { Documento definindo } \\
\text { o que é Tempo } \\
\text { Comunidade e as } \\
\text { responsabilidades dos } \\
\text { professores(as) }\end{array}$ \\
\hline & $\begin{array}{l}\text { Opção } \\
\text { teórico- } \\
\text { metodológica }\end{array}$ & $\begin{array}{l}\text { - Interculturalidade } \\
\text { crítica } \\
\text { - Pesquisa } \\
\text { Participante }\end{array}$ & $\begin{array}{l}\text { Debate grupo } \\
\text { de } \\
\text { professores } \\
\text { Tempo } \\
\text { Comunidade }\end{array}$ & $\begin{array}{l}\text { - Roteiro de } \\
\text { observação e registro } \\
\text { do modo de vida e } \\
\text { saberes tradicionais } \\
\text { - Plano de ação do } \\
\text { semestre }\end{array}$ \\
\hline
\end{tabular}




\begin{tabular}{|c|c|c|c|c|}
\hline $3^{\text {a }}$ Fase & $\begin{array}{l}\text { Métodos de } \\
\text { pesquisa }\end{array}$ & $\begin{array}{l}\text { - Pesquisa } \\
\text { participante } \\
\text { - Etnografia } \\
\text { - Observação } \\
\text { Participante }\end{array}$ & $\begin{array}{l}\text { - Orientação } \\
\text { para coleta } \\
\text { documentos } \\
\text { nos povos- } \\
\text { comunidades } \\
\text { - Leitura e } \\
\text { estudo sobre } \\
\text { metodologia } \\
\text { da pesquisa } \\
\text { participante } \\
\text { - Preparação } \\
\text { Laboratório } \\
\text { Intercultural }\end{array}$ & $\begin{array}{l}\text { - Apresentação } \\
\text { Documento Tempo } \\
\text { Comunidade e } \\
\text { Roteiro } \\
\text { - Laboratório } \\
\text { Intercultural (coleta } \\
\text { documentos) } \\
\text { - Texto Intervenção } \\
\text { Pedagógica no } \\
\text { Tempo Comunidade }\end{array}$ \\
\hline \multirow[t]{2}{*}{$4^{\mathrm{a}}$ Fase } & $\begin{array}{l}\text { Técnicas de } \\
\text { pesquisa }\end{array}$ & $\begin{array}{l}\text { - Observação } \\
\text { Participante } \\
\text { - Caderno de } \\
\text { campo } \\
\text { - Entrevista } \\
\text { - Coleta } \\
\text { documentos } \\
\text { (incluindo } \\
\text { bibliografia sobre o } \\
\text { povo-comunidade) }\end{array}$ & $\begin{array}{l}\text { - Estudos } \\
\text { presenciais } \\
\text { ou a } \\
\text { distância } \\
\text { - Orientações } \\
\text { para trabalho } \\
\text { de campo e } \\
\text { técnicas de } \\
\text { pesquisa }\end{array}$ & $\begin{array}{l}\text { - Plano de ação: idas } \\
\text { às comunidades; } \\
\text { oficinas nos Povos- } \\
\text { Comunidades } \\
\text { - Acompanhamento } \\
\text { presencial e a } \\
\text { distância aos } \\
\text { alunos(as) }\end{array}$ \\
\hline & $\begin{array}{l}\text { Texto narrativo } \\
\text {-descrição ou } \\
\text { análise }\end{array}$ & Sistematização & $\begin{array}{l}\text { - Orientação } \\
\text { sistematizaçã } \\
\text { o - } \\
\text { Preparação } \\
\text { Laboratório } \\
\text { Intercultural }\end{array}$ & $\begin{array}{l}\text { - Laboratório } \\
\text { Intercultural }\end{array}$ \\
\hline
\end{tabular}

Fonte: LICENCIATURA INTERCULTURAL INDÍGENA/Professores do Tempo Comunidade. Registros do processo de elaboração da proposta do tempo comunidade intercultura indígena da UFPE/CAA (2015-2016). Caruaru: Coletânea de relatórios, documentos, textos (não publicado), UFPE-CAA, 2016.

$\mathrm{Na}$ organização das fases da proposta de operacionalização pedagógica apresentada no quadro acima, definimos a perspectiva epistemológica e os referenciais teórico-metodológicos da ação, que chamamos de interculturalidade crítica decolonial, realizada a partir da observação e pesquisa participantes. No processo, delimitamos quais os métodos e técnicas que poderiam facilitar 0 enfrentamento dos desafios políticos-pedagógicos. Elencamos também sugestões de técnicas de pesquisa, registro e sistematização de dados, no esforço de favorecer o diálogo interepistêmico entre conhecimentos da comunidade acadêmica e das comunidades indígenas. Tem papel importante a produção de subsídios, com registro de elementos das culturas e saberes dos Povos, tendo essas informações sistematizadas em textos a serem transformados em suporte para utilização no Tempo Universidade para concretização da interculturalidade crítica como interepistemologia. 


\section{Considerações finais}

A Proposta de Intervenção Pedagógica do Tempo Comunidade intercultural em uma perspectiva interespistemológica foi discutida com a coordenação e com os(as) estudantes. Esse processo de elaboração e discussão demorou aproximadamente um ano, período em que, na Licenciatura, já estavam sendo vivenciados os Estágios Supervisionados (ES), os Trabalhos de Conclusão de Curso(TCC), as ações do Programa de Educação Tutorial (PET/indígena) e do Programa de Iniciação a Docência(PIBID/diversidade), programas e ações que eram vivenciados com os estudantes da segunda turma e não havia articulação entre esses diversos processos, o que criou entre os(a) estudantes uma sensação de sobreposição de atividades.

O curso já se encaminhava para seu final, e como na intervenção pedagógica os(as) estudantes teriam seis meses de pesquisa na comunidade para, no semestre seguinte, sistematizar as informações de forma que pudessem orientar os conteúdos das disciplinas do Tempo Universidade, restou apenas um semestre para que isso pudesse ocorrer. Um pequeno experimento foi feito na disciplina Estágio Supervisionado, mas sem grandes repercussões que pudessem apresentar elementos para uma avaliação sobre a efetividade da proposta na prática.

Além disso, a proposta não foi realizada completando todo o ciclo programado devido à inexistência de condições materiais para deslocamento dos(as) professores(as) do Tempo Comunidade para aldeias, ou mesmo entre aldeias, como no caso dos(as) indígenas, já que no orçamento do curso que a UFPE enviou para o PROLIND não constaram os recursos específicos para deslocamento.

O esforço do grupo de professores(as) do Tempo Comunidade foi tornar o espaço/tempo das comunidades indígenas como territórios epistemológicos, onde saberes/conhecimentos legítimos seriam sistematizados e colocados em diálogo com os saberes/conhecimentos da comunidade acadêmica. Para isso, sugerimos subsidiar os(as) indígenas como pesquisadores(as) das vivências, histórias, práticas, modos de vida, etc. de seus grupos étnicos, de forma que a interculturalidade crítica ganhasse corpo no curso de Licenciatura Intercultural da UFPE/CAA.

\section{REFERÊNCIAS}

ALMEIDA, Eliene Amorim de. A interculturalidade no currículo da formação de professores indígenas no Programa de Educação Intercultural Indígena no Programa de Educação Intercultural da UFPE/CAA - Curso de Licenciatura Intercultural. Recife: Tese Doutorado do PPGE-CE-UFPE, 2017. 
AMGROSINO, Michael. Etnografia e observação participante. Porto Alegre: ARTMED, 2009.

ANDRADE, Flávio Lyra. Construção de identidades coletivas na assembleia popular: trânsitos em processos sociais entre o campo político e religioso. Dissertação de Mestrado em sociologia, PPGS/CFCH/UFPE, Recife. 2012.

ARROYO, Miguel G. Currículo, Território em disputa. Petrópolis, RJ: Vozes, 2011.

BOFF, Clodovis. Como trabalhar com o povo. Rio de Janeiro: Vozes/IBASE, 1984.

BORDA, Orlando Fals. Aspectos teóricos da pesquisa participante: considerações sobre o significado e o papel da participação popular. In: BRANDÃO, Carlos Rodrigues (Org.). Pesquisa participante. São Paulo: Brasiliense, 1982.

BORDA, Orlando Fals. Una sociología sentipensante para América Latina Antología y presentación, Víctor Manuel Moncayo. Bogotá: CLACSO/ SiglodelHombre Editores, 2009.

BRANDÃO, Carlos Rodrigues (Org.). Repensando a pesquisa participante. São Paulo: Brasiliense, 1987.

BRANDÃO, Carlos Rodrigues; STRECK, Danilo Romeu (Org.). Pesquisa participante - o saber da partilha. Aparecida: Ideias\&Letras, 2006, p. 21-54.

BRANDÃO, Carlos Rodrigues. Entre Paulo e Boaventura - algumas aproximações entre o saber e a pesquisa. Rio de Janeiro: FASE, Revista Proposta, n. 113, p. 138148, setembro, 2007.

BRASIL. Referenciais para Formação de Professores Indígenas. Brasília, 2005.

BRASIL. Edital de Convocação no 05. Diário Oficial da União de 26 de junho de 2008. Brasília.

CASTRO-GOMEZ, Santiago. Ciências sociais, violência epistêmica e o problema da 'invenção do outro'. In: LANDER, Edgardo (org.). A colonialidade do saber: eurocentrismo e ciências sociais, perspectivas latino-americanas. Buenos Aires: Clacso, 2005.

COMISSÃO DE PROFESSORES INDÍGENAS DE PERNAMBUCO (COPIPE) - Carta de Pernambuco. Documento final da I Conferência de Educação Escolar Indígena de Pernambuco, ano 2000.

COMISSÃO DE PROFESSORES INDÍGENAS DE PERNAMBUCO (COPIPE). Relatório do VI Encontrão. S/D.

FAVERO, Osmar (Org.). Cultura Popular - Educação Popular - memórias dos anos 60. Rio de Janeiro: Graal, 1983.

FREIRE, Paulo. Cartas a Cristina - reflexiones sobre mi vida y mi trabajo. México: Siglo XXI, 2008.

GADOTTI, Moacir; TORRES, Carlos A.. Educação popular - utopia LatinoAmericana. São Paulo: Cortez/EDUSP, 1994. 
GROSFOGUEL, R. Para descolonizar os estudos de economia política e os estudos pós-coloniais: transmodernidade, pensamento de fronteira e colonialidade global. In: SANTOS, Boaventura de Souza; MENEZES, Maria Paula (Org.). Epistemologias do Sul. Coimbra, Portugal: Cortez, 2010.

LICENCIATURA INTERCULTURAL. Projeto Político Pedagógico Do Curso. Licenciatura Intercultural Indígena. Universidade Federal de Pernambuco (UFPE/CAA). Caruaru, 2014.

LICENCIATURA INTERCULTURAL INDÍGENA. Orientação para a realização do tempo comunidade no âmbito da licenciatura intercultural indígena. In: LICENCIATURA INTERCULTURAL INDÍGENA / Professores do Tempo Comunidade. Registros do processo de elaboração da proposta do tempo comunidade intercultura indígena da UFPE/CAA (2015-2016). Caruaru: Coletânea de relatórios, documentos, textos (não publicado), UFPE-CAA, 2016.

MIGNOLO, Walter. Historias locales-diseños globales: colonialidad, conocimientos subalternos y pensamiento fronterizo. Madrid: Akal, 2003.

MOURA, Abdalaziz. Principios e fundamentos de uma proposta educacional de apoio ao desenvolvimento sustentável - PEADS. Uma proposta que revoluciona o papel da escola diante das pessoas e do mundo. Glória de Goitá: SERTA, 2003.

PAIVA, Vanilda Pereira (Org.). Perspectivas e dilemas da educação popular. Rio de Janeiro: Graal, 1986.

PONTUAL, Pedro; IRELAND, Timothy (Org.). Educação Popular na América Latina: diálogos e perspectivas. Brasília: Ministério da Educação/UNESCO, 2006.

PROJETO PEDAGÓGICO DO CURSO. UNIVERSIDADE FEDERAL DE PERNAMBUCO (UFPE/CAA). Programa de Formação de Professores Indígena do estado de Pernambuco - Curso de Licenciatura Intercultural em educação intercultural. Caruaru, 2006.

ROSAS, Paulo (Org.). Paulo Freire - educação e transformação social. Recife: Centro Paulo Freire/Ed UFPE, 2002.

SANTOS, Boaventura de Souza. Para além do pensamento abissal: das linhas globais a uma ecologia dos saberes. In: SANTOS, Boaventura de Souza; MENEZES, Maria Paula (orgs.). Epistemologias do Sul. Coimbra, Portugal: Cortez, 2010. p. 31-83.

SARTORELLO, S. C. Una perspectiva crítica sobre interculturalidad y educación intercultural bilingüe: El caso de la Unión de Maestros de la Nueva Educación para México (UNEM) y educadores independientes en Chiapas. Revista Latinoamericana de Educación Inclusiva. 2009, pp. 77-90. Disponível em:

http://www.rinace.net/rlei/numeros/vol3-num2/art5.pdf. Acesso em: dez. 2012.

SOUZA, João Francisco. Atualidade de Paulo Freira - contribuição ao debate sobre a educação na diversidade cultural. Recife: Bagaço/NUPEP, 2001.

SOUZA, João Francisco (Org.). Ivestigación-acción participativa: qué? Desafios a la construción colectiva del conocimiento. Recife: NUPEP/Bagaço, 2006.

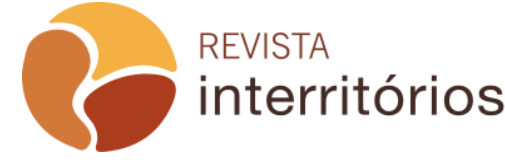


STRECK, Danilo R.; ESTEBAN, Maria Teresa (Org.). Educação Popular - lugar de construção social coletiva.Petropólis: Vozes, 2013.

THIOLLENT, Michel Jean Marie. Pesquisa Ação. São Paulo: Cortez, 1986.

THIOLLENT, Michel Jean Marie. Notas para o debate sobre pesquisa-ação. In.: BRANDÃO, Carlos Rodrigues (Org.). Repensando a pesquisa participante. São Paulo: Brasiliense, 1987.

TUBINO, Fidel. Del interculturalismo funcional alinterculturalismo crítico. 2005. Disponível em: http://fongdcam.org/wpcontent/uploads/2012/01/delinterculturalismoTubino.pdf. Acesso em: set. de 2013.

UNIVERSIDADE FEDERAL DE PERNAMBUCO. Processo Seletivo para o PROLIND - UFPE - Licenciatura Intercultural Indígena. Edital 01/2015.

WALSH, C. Interculturalidad, Plurinacionalidad y Decolonialidad: Las Insurgencias Político-Epistémicas de Refundar el Estado. Revista Tabula Rasa. Bogotá, Colombia, n. 9, p. 131-152, julio-diciembre, 2008.

WALSH, C. Interculturalidade Crítica e Pedagogia Decolonial: in-surgir, re-existir e reviver. In: CANDAU, Vera Maria (org.). Educação Intercultural na América Latina: entre concepções, tensões e propostas. Rio de Janeiro: 7letras, 2009a.

WANDERLEY, Luiz Eduardo W. Educação Popular - metamorfoses e veredas. São Paulo: Cortez, 2010. 